Article

\title{
Future of Catholic Monasteries on New Monastic Continents: The Case of Africa
}

\author{
Isabelle Jonveaux \\ Institute of Religious Studies, University of Graz, 8020 Graz, Austria; isabelle.jonveaux@uni-graz.at
}

Received: 4 July 2019; Accepted: 31 August 2019; Published: 4 September 2019

\begin{abstract}
Catholic monasticism in Europe is often associated with a crisis of vocations, of credibility and sometimes the question of closing down. Looking at monasteries outside Europe, especially in Asia and Africa, we observe a dynamic of new foundations and young entrants into the communities. What are the challenges for monasteries in Africa in future decades? To what extent does monasticism experience a gravitational shift from Europe to other continents in the next thirty years? This article seeks to explore the challenges of African monastic communities now and in the future. The first part gives some demographic data which shows the dynamism of African monastic communities. The second part deals with the adaption of monastic life in the local environment; for instance, concerning the liturgy but also the role of the development of monastic communities. In the last part, I discuss the challenges of African monasticism, which is becoming autonomous from its European founders and developing more and more indigenous foundations. This article is based on field inquiries conducted in monastic communities in five countries in Africa between 2013 and 2019.
\end{abstract}

Keywords: Catholic monasticism; Africa; cultural transfer; development

\section{Introduction}

Monasticism in Europe is often associated with a crisis of vocations, of credibility and sometimes the question of closing down. Demographical statistics of congregations show a high average age with a significant proportion being over 70 and a low rate of new members joining. A monk in Belgium, whom I met in 2008 during a field inquiry, spoke about the end of monasticism and, in another community, a plan B for the moment when the community will be too small to live in the big building. Will Catholic monasticism die? Indeed, according to the Alliance Inter Monastique, we can count 68 closures of monasteries in Europe between 2000 and 2014. This apocalyptic description has nevertheless to be moderated, taking into account the 41 new foundations in Europe in the same period and the dynamism of some new monastic communities (Palmisano 2015).

Studying Catholic monasticism, it is important to take a look at monasteries outside Europe. Today, Roman Catholic monasticism exists in all countries where Catholicism is widespread, even if it is officially forbidden, such as in China. The Order of Saint Benedict (OSB) catalogue lists 1185 Benedictine communities spread across 80 countries. Trappists include 102 male and 76 female monasteries ${ }^{1}$. Looking at monasteries outside of Europe, a different situation presents itself. For instance, in Asia or Africa, vocations do not appear to constitute a problem.

Will Catholic monasticism experience a gravitational shift from Europe to other continents within the context of religious modernity? Demographic statistics of communities and foundations seem to be particularly dynamic in Africa, where monastic life is still new. Actually, Roman Catholic monastic

1 For 2015. http://www.ocso.org/monasteres/current-statistics/?lang=fr. 
life has its origin in the monasticism of the deserts of Syria and Egypt during the first centuries of our era. The institutionalization of monastic life in regulated communities began with Pachomius $(† 346)$ in Egypt and the redaction of his rule (Cousin 1956). As Casier notes, "we must not forget that eremitic life and monasticism, during the first centuries of Christianity, took place in Africa, and more especially in Egypt. Saint Augustine, an African too, was one of the pillars of monasticism" (Casier 1974, p. 137). But the institutionalization of the present form of Roman Catholic monasticism occurred effectively in Europe during the sixth century with the Rule of Benedict in Italy, which spread rapidly. Charlemagne imposed the Rule of Benedict for all monasteries of the empire, and also for nuns (Hasquenoph 2009, p. 458). In this sense, the long history of European Catholic monasticism left its mark on Catholic monasticism itself.

The evangelization of sub-Saharan Africa in its present form occurred especially in the nineteenth century but the Catholic Church remains very young in many of these countries. If we take countries I especially deal with in this article, we observe different religious situations. Senegal is predominantly Muslim with 94\% Muslim and only $4 \%$ Roman Catholic. In Togo and Benin, approximately $30 \%$ of the population is Christian and traditional religions are still practiced by a majority of people. The first diocese was founded in 1892 in Togo and, in 1883, in Benin. But north Benin, where I studied two monasteries (in the region of Parakou), has been evangelized for less than 80 years. This means that the first generation which was evangelized is still alive and presents priests, nuns and monks who often come from families who converted to Catholicism or where the parents belonged to a traditional religion. The diocese of Parakou was founded in 1948. At last, the predominant religion in Kenya is Christianity ( $85 \%$ ), with $23 \%$ of Christians identifying as Catholic. The religious situation of a country is important to take into account in order to better understand the challenges for a community to accept, in the local environment, the role of monastics for the acculturation of the Catholic religion.

This article endeavors to explore monastic life outside of Europe in newly founded communities in Africa. What is the future of these new foundations in Africa? What are the present challenges, so that they manage to build a monastic tradition in Africa? To what extent do the monastic dynamics in Africa renew the monastic charisma, compared to Europe?

\section{Inquiry}

So far, I have studied contemporary Catholic monastic life in seven countries in Europe, Argentina, and five countries in Africa, but I will focus here on African monasticism. This article is based on multilocal empiric inquiries with half-structured interviews and participant observations in Catholic monasteries in Togo, Kenya, Burkina Faso, Senegal and Benin. Field inquiries were carried out between 2013 and 2019, mainly in 12 communities from the Benedictine and Trappist orders. I conducted 50 interviews with monks, nuns, abbots and abbesses of these communities. Within the scope of my field inquiries outside Europe, I limited the focus to monasteries under the Rule of Benedict in order to investigate specific phenomena within a particular socio-cultural context and the cultural transfers thereof. The Benedictine family can be seen as a representative example for such research as it is the most widespread monastic rule worldwide for Roman Catholic monasteries and includes both male and female communities. It comprises three main orders: Benedictine, Cistercian and Trappist. Here, I will especially use interviews of field inquiries in six monasteries:

- The monastery of Agbang, belonging to the Benedictine Congregation of Saint Ottilien, was founded by a local monk, Father Boniface Tiguila in 1985. I spent more than two weeks there for a field inquiry in April 2013. I conducted six interviews and ethnographical participant observation.

- $\quad$ Our Lady of Mount Kenya, a Benedictine priory of the Congregation of Saint Ottilien, founded in 1979 by German monks, where four monks live. I visited in March 2014.

- The Benedictine abbey of Keur Moussa, founded by the French abbey of Solesmes in 1962. I conducted two field inquiries: the first in July 2016, when I conducted nine interviews; and the 
second, in cooperation with Dr. Muhammad Bâ (University of Saint Louis, Senegal), in March 2017, when we conducted six interviews.

- $\quad$ My last inquiry in March 2019 included three monasteries in Benin: the female Benedictine monastery of Toffo, founded by the French monastery of Saint Bathildes of Vanves in 1966 (four interviews); the male Trappist monastery of Kokoubou, founded by the French abbey of Bellefontaine in 1972 (four interviews); and the female Trappist monastery of L'Etoile Parakou, founded by the French abbey of Notre-Dame des Gardes in 1960 (nine interviews).

\section{From a Statistical Point of View}

\subsection{Demographic Shifts in European Communities}

For demography in Europe, the main question concerns the future of monasticism, which actually hides other challenges of present monastic life (Jonveaux 2018b, p. 121). If we consider demographic statistics for Western Europe, we observe that communities often have a high average age and a low rate of entrants. For instance, in the Benedictine Congregation of Subiaco in France in 2014, four of the five female communities and four of the seven male communities have an average age over 70 . This naturally has consequences about the dynamic of community life and economy, for instance, but also about the form(s) of asceticism (Jonveaux 2018a, p. 80). For Italy, where the number of nuns and monks is the highest in Europe, Giovanni Dal Piaz identifies a radical decline in the last fifty years: "The number of cloistered nuns has decreased from 12.863 to 5.828 by 2011, a decline of 55\%" (Dal Piaz 2014, p. 40). Concerning the rate of entry, I could calculate for the monastery of Kremsmünster in Austria that the community had on average two stable entrants each year in the 1950s, then one stable entrant in the 1960s and 1970s and 0.5 each year since the 1980s. Bernhard Eckerstorfer, a monk of this abbey, notes: "In my own abbey of Kremsmünster, during the last decade, more monks have left than have entered and remained. We are now fifty-six, while thirty years ago we were over ninety." (Eckerstorfer 2013, p. 527)

Linked to this demographic evolution, a new phenomenon can be observed-long-established European communities no longer send members to their foundations abroad but call members of these foundations home to overcome the reduction and the ageing of their community. Dal Piaz noticed for female monasteries in Italy that "forty-two percent of cloistered communities currently include foreigners" (Dal Piaz 2014, p. 43). Especially for nuns between 20 and 29 years old, 60.2\% are foreigners (Dal Piaz 2014, p. 43).

If we compare this with other continents, we note younger average ages for Asia and Africa for many communities and a high rate of entry. I could not create statistics for the population of the Benedictine order as a whole, but the communities of the Benedictine Congregation of the Annunciation can serve as an example ${ }^{2}$. The average age in communities in Africa is 42 and almost 40 in Asia. Compared to Europe (62), this is very low. The minimum age is lower in Asia (19) and Africa (21), which indicates that people enter monastic life at a younger age than in Europe (23). The maximum age is also lower in Africa (77) due to the general life expectancy being lower than in Europe (95). According to the 2004 OSB Catalogue, the Benedictine monastic population is still concentrated in Europe as 55\% of Benedictine monasteries are in Europe, $9 \%$ in Africa and $11 \%$ in Asia. But the lower average age and higher numbers of new members in Asia and Africa predict a coeteris paribus, a shift in global monastic dynamics in future decades.

2 These statistics are based on official catalogues of orders and/or congregations. Each Benedictine congregation has a list of communities and members, including date of birth, of entry, profession, etc. 


\subsection{Dynamic of Foundations}

It would be wrong to consider that Christian monasticism is a totally novel import of the nineteenth and twentieth century in sub-Saharan Africa. According to the legend of the Nine Saints, native monasticism in Ethiopia emerged in the fourteenth century as introduced by Orthodox Christian monks. The biggest monastery was founded in the fourteenth century in the forest of Waldebba and still counts over a thousand monks today. Nevertheless, concerning Catholic monasticism, the first monasteries were founded by German monks of the Congregation of Saint Ottilien in Tanzania at the end of the nineteenth century. In 1887, the Holy See had asked the Congregation of Saint Ottilien to evangelize East Africa. In other parts of Africa, especially in West Africa, a new wave of foundations appeared in the 1960s after the encyclical Fidei Donum (1957) was published, in which Pope Pius XII urgently called people to the missions in Africa (Zorn 1994, p. 57). Monastic foundations in Western Africa were often the result of a request of the local bishop and the possibility for a community or the project of one community to found a new community. One condition is that the founding community has enough members to send to the foundation. For instance, the foundation of the Benedictine monastery of Keur Moussa in Senegal was founded at the request of the bishop of Dakar, who was at the time Monseigneur Lebfevre. The foundation of the female Benedictine monastery of Toffo in South Benin was called for by Bishop Gantin (who was made a cardinal in 1977), as he was native to this region. The aim of the bishops is often to establish a contemplative monastic presence in their diocese. A French sister of the monastery of L'Ecoute Pèporiyakou, the second to last monastery founded in Western Africa, explains: “The idea of Mgr Pascal, when he called us, was to have a monastery in his diocese. It was one of his three objectives when he was appointed bishop, to have a monastery, a diocesan Marian center and to initiate work for a new cathedral." (03.2019).

As illustrated in Figure 1, according to the statistics from the Alliance Intermonastique (AIM), foundations of Roman Catholic monasteries in Asia and Africa are a fairly recent phenomenon:

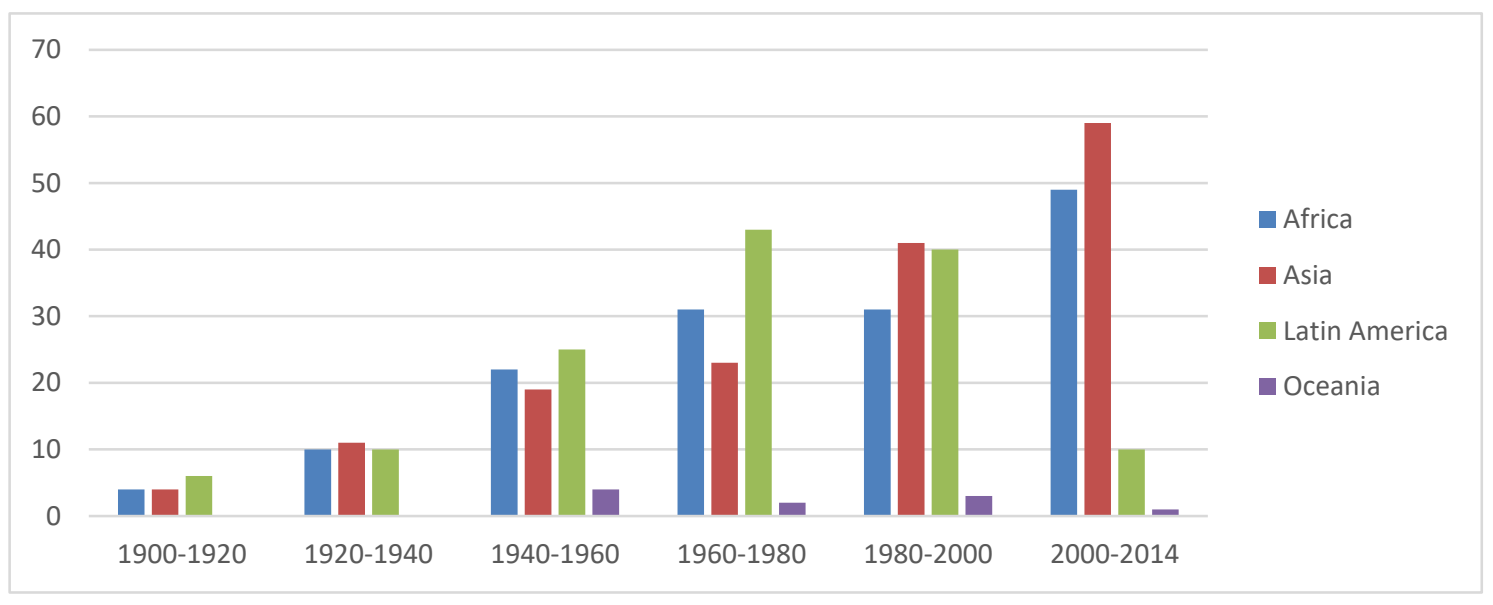

Figure 1. New foundations 1990-2014. Martin Ney, 2000, Geraldo Gonzales y Lima, AIM, 2014.

We can see here that there were 49 new foundations in Africa in the last period-the second continent with the most foundations after Asia.

\section{How to Adapt Monastic Life in Another Culture}

\subsection{To Build Monasticism in a New Cultural Context}

Following Jean Séguy, we consider the monastery as a utopia which he defines as "a complete ideological system aiming to transform radically the existing global system implicitly or explicitly, by appealing to an imaginary vision of the world or by applying it in practice" (Séguy 2014, p. 288). A utopia inevitably exists in a state of tension, as it tries to embody the eschatological, which has not 
yet happened, in the present. Monasteries are confronted with the "fatal dilemma of each utopia" (Hervieu-Léger 2017, p. 232). Practiced utopia is never stable and needs to justify itself with respect to written utopia and society. Justification to society refers to its plausibility. Thus, a utopia is in a constant renegotiation of compromises between the real world and the ideal model. These negotiations can be observed in particular in the case of foundations or re-foundations, as monasteries need to justify themselves with regard to existing monasticism and establish their plausibility within society. In this respect, newly founded monasteries during the first charismatic period or the routinization period serve as laboratories to examine the creation of a utopia and its integration into society.

African monasticism was established in a context where monastic life was, most of the time, not known, whereas apostolic religious life was present in the public space. A lot of these congregations came with European colonization and developed social engagements like schools and a dispensary. When they arrived in a region, monks and nuns are often considered by the local population as apostolic brothers and sisters from whom they awaited social activity. Father Catta, one of the first monks of Keur Moussa in Senegal, explains that they had to affirm at the beginning: "we are not missionaries, we are contemplative monks" (Interview 07.2016). The first challenge of monastic life is, therefore, to establish the specificity of monasticism.

Monastic communities in Africa are, therefore, confronted with the question of constructing a monastic utopia. The main challenge for monastic life is to distinguish itself from the apostolic religious. It is a characteristic of monasticism to be, according to Max Weber, "out of the world" (Weber 1972), so as not to be active for the world. In other words, monastic life has to affirm its contemplative dimension and its "usefulness" (Merton 1975, p. 23). When they arrive, monks and nuns often have to answer to a local demand for social needs, even if they consider that it is not their vocation. As a monk of Keur Moussa said in an interview: "Women came to the monastery to find help for a birth, and the monks had to do it although it is not a mission of a monk to do it!" (Interview 07.2016). Similarly, in the Benedictine monastery of Toffo in Benin, a French nun who was sent to the community two years after the foundation, in 1968, explains: "It was not our vocation, but it was a necessity" (Interview 03.2019). Another sister of the same community explains:

They began [to have social activities] but they said, over time, it will be forgotten, or it will be said that we are not here for something else. To want to live a monastic life. It will be said, they never were like that, it will not be understood by the new generations. So, we have to get it right from the start. They asked the cardinal to bring a religious community to the parish. They also built the church in the parish. [... ] Otherwise, at the end, people will come to the monastery and no longer to the parish. It will be ambiguous. So they have wished clarity from the beginning. [ ... ] And they managed to do it. [ ... ] For first aid, it was clarified since the beginning. There are communities, which had to open a dispensary. And they are no longer able to cut it. Our sisters did the transition well. (Interview 03.2019)

In the female Trappist monastery of L'Etoile Parakou in North Benin, the situation was different. Three monks of the same congregation were sent one year before, in 1959, in order to build the monastery before the nuns came. A French nun who came in 1962 explains: "The first nuns arrived the first Advent Sunday in 1960. They could start monastic life right away, the very next day, correctly because they found all the buildings. [ ... ] They found a chapel, a refectory and places to sleep." (Interview 03.2019) However, at the beginning, they had a small dispensary, which was developed into a real hospital, but which was transferred to the next city as it became bigger. The sister says, "We called a male nurse, so that we do not need to work in the dispensary so that the monastery stays a monastery, without confusion in the mind."

Another challenge in the construction of a utopia is acceptance in the local environment. Monasticism has not, as a first goal, to be a part of society but to contest some dimensions of present society and to build itself as different. Nevertheless, a monastery has to be accepted to limit the tensions with the surrounding area. Conflicts with the local population sometimes happen, especially 
land disputes. This was the case of the Trappist monastery of Our Lady of Victoria in Kenya ${ }^{3}$, which had to move to Uganda in 2008 because of violent tensions with the local population. Koudbi Kaboré ${ }^{4}$ observed the same kind of tensions for the monastery of Diabo and Anne Diah for the monastery of Bafor, both in Burkina Faso, when the sisters tried to extend their land. Monastic utopia has, therefore, a geographical dimension, which can conflict with the non-utopian space.

\subsection{Cultural Transfers to Root Monasticism in the Local Environment}

The development of monasticism in Africa is only possible if monasticism is permanently anchored in the local culture and environment. Monasteries in Africa have often been initially founded by European communities. If we consider African monasteries listed on the homepage of the AIM, the majority were founded by European communities from 10 different countries, especially France and Belgium (20 each) in their ancient colonies. The founders brought their way of life and culture as well as the monastic model of their respective country with them. At the beginning, monasteries were not always open to local novices. In Tanzania, the first monastery founded by the Congregation of Saint Ottilien in 1898, Peramiho, only started to accept African monks into their community in the 1980s (Tiguila 2011). Cultural transfers to adapt monastic life in the local context are nevertheless necessary to embed monastic life in the African context, when the founder communities from Europe no longer send monks to the foundations.

I choose here not to use the term "acculturation," as this notion can be ambiguous due to its having been developed in Europe in the context of decolonization. At the same time, the Church developed the emic concept of "inculturation", which considers traditional religions as a preparatory precursor for Christianity (Metogo 1985), and which, therefore, takes place in a context of domination. This is the term nuns and monks use in the interviews. The concept of cultural transfer is used herein, as it does not consider each cultural space as inherent, but as a product of previous hybridizations and mutations (Espagne 2013, p. 3). It is necessary to consider that the confrontation between two cultures is a process, not a result (Ripert 2010, p. 9).

It is not possible here to describe all dimensions of cultural transfers in monastic life, but I will focus on the question of liturgy. Liturgy is one of the dimensions of monastic life where we can observe cultural transfers with the most intensity. Monastic communities which were founded at the beginning of the 1960s came to Africa with their own liturgy, so did the Latin language and Gregorian chant as it was also in Europe at this time. As Father Catta of Keur Moussa in Senegal explains it in an interview (07.2016), it was not the aim at the beginning to change the liturgy. Latin and the Gregorian chant were considered the monastic liturgy for the whole Catholic Church. But the Second Vatican Council opened the door first to use vernacular languages and second to adapt the liturgy to the local culture, so to the African culture. The Abbey of Keur Moussa, which was founded by the French abbey of Solesmes in 1963, is the most well-known example of the adaptation of Gregorian liturgy in West African culture (see Sarr 2013, 2015). The abbey of Solesmes is itself famous in France for its Gregorian liturgy, which was reintroduced by Dom Guéranger, founder of the monastery, at the end of the nineteenth century. After the publication of the documents of the council encouraging the adaptation of the liturgy to the local culture, the abbot of Solesmes asked a monk of Keur Moussa, Father Dominique Catta, to carry out the work of the adaption of the monastic liturgy in the African culture. He travelled through different countries of West Africa and collected melodies of traditional music, which he combined when composing the tones for the psalms. According to him, this adaptation was possible because there is a connection between Gregorian music and traditional African music. The monks of Keur Moussa also developed and improved a traditional instrument, the kora, which they started to

3 I met a monk of this community, in 2014, at the Benedictine student house in Nairobi.

4 Koudbi Kaboré, University of Ouagadougou I, and Anne Diah, University of Bobo, took part in the project "Contemplation and social engagement of monasteries in Western Africa". Dr. Katrin Langewiesche, project leader, invited me twice to Ouagadougou for a workshop with the students and asked me to accompany the students in their research. 
make in the monastery as one of their main economic activities. The kora is a Mandinka harp with 21 strings, which is made of a half calabash covered with a cow skin and a long neck of vène wood. It was traditionally played by men for religious ceremonies. This liturgy has become widespread in the whole of West Africa as I could observe it during my inquiries in Togo, Benin and Burkina Faso. It does not mean that these monasteries adopt the liturgy as a whole but they are taking some elements, especially the use of the kora of Keur Moussa. As the monks and nuns explained to me in Benin this year, they could have sessions to learn the kora either with a monk of Keur Moussa who came to Benin or by going to Senegal themselves.

Yet we have to note that this work of the adaptation of the liturgy was not carried out by a local monk but by a French monk. As Father Catta died in August 2018, the question arises as to whether there will soon be a second wave of adaptation led by local monks. Indeed, young monks of Keur Moussa told me that they think it would be important to have more songs in local languages and to further include local adaptations. Kabasele Lumbala underlines that the conception of "inculturation" by the Catholic Church itself "consists in giving the initiative to the Africans people" (Lumbala 2011, p. 433). An association to reflect on acculturation in monastic life was founded in Togo and the Ivory Coast with the help of the ethnologist Clémentine Madiya Faik-Nzuji (UCL): Association Monastique de Réflexion sur les Symbolismes dans les Cultures Africaines. This association works on the composition of liturgical texts and music, the translation of spiritual texts into local languages and the integration of religious life into the African traditions (Adom 2001, p. 29). Parallel to this, the network Répertoire Monastique d'Afrique de l'Ouest (REMONAF) for work on the liturgy has been developed in Togo, the Ivory Coast, Benin and Burkina Faso. With the help of a French music teacher, communities work on the cultural adaptation of their liturgy by composing new songs in French with local music intonations. This work is, therefore, an ongoing process, especially concerning the local languages when the monastery is located in a context with a lot of local languages. As there are more than 70 languages in North Benin, the common language of the liturgy in the monasteries is French. In the Trappist monastery of Kokoubou, none of the monks come from the ethnic group where the monastery is situated. According to a monk of this monastery, the challenge for the adaption of the liturgy in future decades is the language. He says, "we like to speak French, but it is not our mother language. [ ... ] So we have this concern that our liturgy becomes really enculturated" (Interview 03.2019).

Socio-cultural transfer not only happens in a single direction but can be a two-way exchange. Indeed, more and more monasteries in Europe are using the kora of Keur Moussa for their liturgy and some communities in France are also using the liturgy of the African monastery in order to renew and give a new dynamic to their liturgy. In addition, more koras of Keur Moussa were sold in Europe (942 until 2014) than in Africa (899).

\subsection{Monasteries as Actors of Development}

Monastic life in Africa plays an important role in the development of its region, as we can observe it in the long history of monasticism on other continents; for instance, in Europe in the Middle Ages (see Schmitz 1949). In developing countries, monastic communities often have to meet the demands of society regarding education and healthcare.

Monasteries from the Benedictine family have in their tradition developed, in and around the monasteries, the kinds of activities that can provide for the subsistence of the community. For a new foundation in Africa, it often means at the beginning that monks and nuns will develop the possibilities of agriculture. For instance, the motto of the abbey of Keur Moussa in Senegal is, "And the desert will start flowering" (Isaiah 35:1), and indeed they transformed the desert in which they are in into arable lands, introducing also a lot of new species to this environment. The employment of local salaried workers also contributes to local development, giving work to people around the community. It also helps to integrate the monastery into its environment. For a Kenyan Benedictine monk of Our Lady of Mount Kenya, the employment of local people is the main dimension of their development activity. The formation of monks and nuns is another part of direct development, which is also necessary 
for monastic life. As Katrin Langewiesche notes for female monasteries in Burkina Faso: "It is very difficult to make the monastic lifestyle understandable and clear for young girls if they have no school education" (Langewiesche 2017, p. 68).

Civil society also becomes interested in the role of the development of monasteries. For instance, in Senegal, the president of the Republic, who is himself Muslim, showed interest in cooperating with the Benedictine monastery to further the development of the country. He gave a solar dryer he received as a gift from the president of Thailand to the monastery, as he thought the monastery was the best place for it. Katrin Langewiesche also notes for the female monastery of Koubri in Burkina Faso where NGOs have begun to support some activities of the monastery: "[ ... ] International organizations like the World Bank and small NGOs have identified the potential of the monasteries as catalysts for economic development, and support monastic projects in the area of sustainable development, food self-sufficiency, and the protection of biodiversity. For example, Koubri received support from an international program (Global Environment Facility (GEF), United Nations Development Program (UNDP) and United Nations Office for Projects Services (UNOPS)) for the conservation of biodiversity." (Langewiesche 2015, p. 139)

Contrary to an apostolic congregation, such social development is not included in the definition of monastic life, but even monasteries are not acting directly for the development it "comes with," as the abbot of Keur Moussa put it. It is, therefore, a positive external force which changes the social and economic environment of the monastery. However, some monasteries have a direct action plan for development. Speaking about his monastery in Uganda, Father Isaac, whom I met in Nairobi in the Benedictine Student House, explains:

The activities of the monastery, they have a school. The orientation wants to bring basic human development on the background of agriculture and schools and medical services. So you open a school to train them to do something for themselves so that they can come and get the skill, maybe of building, carpentry; maybe repairing bicycles or motor vehicles, then they go and establish themselves to do something on their own. [ ... ] So these were the basic projects which started to bring basic human development, which helps people who did not go high in their academic levels to at least find a way of living well, to establish themselves. (Interview 03.2014)

According to the charisma of the community, this development activity can be more or less direct, but a monastery is always a center of development and improvement of life conditions for the surrounding populations. For instance, in all monasteries I visited in Togo and Benin, Peul people around the monastery come to charge their mobile phone in the monastery as they have no electricity in the bush and communities let them dig wells for safe drinking water near the camps.

\section{Challenges for African Monasticism in Future Decades}

Despite the apparent dynamism of its communities, African monasticism is presently confronted with diverse challenges which will decide whether this monasticism can really take root in this continent in future decades. The statistics of the new foundations given above do not occlude the closing down of other houses. According to $\mathrm{AIM}^{5}, 49$ communities were founded in Africa between 2000 and 2014, and 12 were closed. These were often mission houses. This means that the social role of monasteries is changing in these countries and that a new foundation does not necessarily mean that it will stay and develop itself. In fact, not all foundations in Africa manage to live longer than thirty years.

5 http://www.aimintl.org/fr/2015-05-29-13-29-48/2015-06-23-12-55-30/fondations-fermetures. 


\subsection{Turning Point of African Communities}

Nowadays, African communities are at a turning point. They are progressively moving away from European influences and are founding their own communities. European people who came to found these communities will no longer be seen in the communities either because they returned to Europe for health reasons or because they passed away. In addition, European communities no longer send members to Africa because they are already too small and too old.

The fact that African communities, which were founded by European communities, will soon have no European members has at least two important consequences. The first concerns continuity. European founders assured the continuity of monastic tradition between the "mother abbey" and the "daughter community" in the long "chain of memory" 6 . According to Delpal, unlike the Church, monasticism cannot base itself on a divine foundation and requires a tradition to establish its legitimacy (Delpal 1998). In this process of evolution from the "mother abbey" to the "daughter abbey", which in turn also founds new communities in their respective or neighboring countries, the question of which processes are faithful and which break with tradition arises. During my field inquiry in Argentina in 2015, I observed that monasteries, such as Niño Dios (Entre Rios), adapted the Gregorian Latin liturgy in the last decade to affirm their affiliation with traditional European monasticism. I could note the same situation in the female Trappist monastery of L'Etoile in North Benin, which began to use again Latin in the liturgy. For the nuns, it is a sign to integrate their community into the monastic tradition. On the other side, the whole Africanization of the communities give them the opportunity to carry out a second step of the adaptation process, which is no longer performed by European monastics but by the African monastics themselves. Now almost all communities in West Africa have a local abbot or abbess. A French Benedictine sister of Notre Dame de l'Ecoute in Benin, the second to last monastery founded in West Africa, explained that there are only two European people at the meeting of the masters of novices for West Africa. The situation can be yet different between male and female monasteries. Field research in Kenya in 2014 showed that male monasteries of the Benedictine congregation of Saint Ottilien are led by an African monk, while the female community from the congregation of Tützing in Nairobi has no African nuns in positions of responsibility. The prior comes from the USA, the master of novices from Germany and the cellerer from China.

The second consequence is economic. In France, monks and nuns have to pay for social security contributions and they then receive a pension. African communities which were founded by French communities still benefit from these pensions either because some French monastics are still in the community or because monastics who returned back to France still send their pension to the communities. Compared to the local buying power, these pensions are an important part of incomes for a community. For instance, in the Benedictine female monastery of Toffo in Benin, the pensions represent $36.9 \%$ of all the revenue of the community in 2015. It is the same in the Trappist male community of Kokoubou, also in Benin, where the pensions are the first source of income, accounting for $38.9 \%$ of the revenue. They come from four French monks, one of whom is now in France ${ }^{7}$. This means that these communities have the urgent need to find new sources of incomes in order to replace the pensions in the near future, ideally before the French monks die. The economy of African monasteries has also to find new ways of development as some activities were initiated by European monks and nuns with their own conception of a monastic economy. Studying different countries in Europe, I observe that monastic economy is directly influenced by the political and religious history of individual countries (Jonveaux 2011, 2018b). This means that European communities often brought their monastic economic model to Africa. For instance, all monasteries I visited in Benin are producing jam, whereas this product does not belong to the local culture and is purchased only by

6 I refer here to the title of the book of Danièle Hervieu-Léger: Religion as a chain of memory (Hervieu-Léger 2000).

7 Thank to André Ardouin, a French monk, who conducts controls finances for European and African monasteries, I had access to the accounting reports of 15 communities. 
rich people. This turning point will, therefore, also mean a development of new forms of activities for African communities.

\subsection{Towards an African Monasticism?}

The second turning point of African monasticism today is that communities which are presently being founded in Africa are, most of the time, founded by African communities or individual African people. It means that the communities that were founded by European or American communities are now becoming themselves mothers of new communities. For instance, the abbey of Keur Moussa founded, in 2011, the monastery of Segueya in Guinea Conackri. An interesting example comes from Togo with the project of Father Boniface Tiguila of founding "an African monasticism by an African monk, for African people". At the beginning of his monastic life, he entered the only Benedictine monastery in Togo at the time, Dzobegan, which was founded in 1961 by the French Benedictine monks of En Calcat. According to him, this form of monasticism, which is influenced by the French contemplative model, was not adapted to African society. He says that he was "looking for a kind of monastic life which is very simple, closer to the people and more African" ${ }^{8}$. After spending six years in this community and travelling through Europe to observe different forms of monastic life, he left his community to pursue the project of establishing a new African community. To explain his project, he wrote a "small book for African monastic life", which takes Benedictine spirituality and tries to adapt it to the African cultural context and to local needs. Here, we observe the affirmation of a breaking away from the model of the French founders. The new monastery was institutionalized by entering the German Congregation of Saint Ottilien in 1991, followed by the erection as an abbey in December 2016.

The monastery of Agbang has as an explicit goal to root monasticism in the local culture. In this case, cultural transfer takes place as a conscious act of adaptation. Adaptation to the local culture occurs in different domains. Firstly, the local language (kabyè) and African music (kora from Keur Moussa, jumbeeaso) are integrated into the liturgy. Then, the habit is adapted to the climate and socio-economic environment: kaki habit for the liturgy and white habit for special occasions. Particularly interesting is the chest tattoo monks get upon their solemn profession with a cross and the name of their monastery. According to a monk of this monastery, it refers to the "seal of the living God" (Revelation 7:2). This is as much a symbol of the Monastère de l'Incarnation as it is a traditional rite in the kabyè culture, where young men are tattooed as part of their initiation. Monks can then show that they belong to Christ and that their new family is the monastery (Adom 2001, p. 35). The architectural design of the monastery is a dialogue between African architecture (round buildings) and traditional monastic architecture (cloister, water tower in the center, etc.).

The example of Agbang shows a case of a monastery which was, from the beginning, founded by a local monk. Boniface Tiguila himself belongs to the local ethnic group of kebyè. In this sense, we might consider that the acceptation of monastic life in the local environment is easier when compared with the monastery founded by foreign people. But monastic life is also a utopian "micro-society" (Séguy 2014, p. 288), which builds itself in contradiction with the surrounding society, as already said. This means that some dimensions of monastic life can, nevertheless, cause tensions with the local culture or population. For instance, in Agbang, when the first monk died in the community, a conflict occurred with the family as they wanted to take the body because it is important in the local tradition, although the monastic tradition states that monks are buried in the cemetery of the monastery. Some conflicts also appear because of the wood in the forest surrounding the monastery.

This model of indigenous foundation - in Africa from African people-may be the model of monastic foundations in the near future. Father Tiguila has, for instance, a project to found a community in the Central African Republic.

8 Website of the monastery: http://www.agbang.org/welcome.html [consulted on 2 June 2019]. 


\subsection{Towards the Autonomy of African Monasticism}

Until the 1990s, monasteries in southern countries were not considered as independent monasteries but overseas establishments of European or US-American monasteries. This took place within a context of missions, which could be linked with some forms of domination (Habermas 2008). Today, African monasteries are becoming more and more independent; firstly because European monks and nuns are no longer present or in fewer numbers, and secondly because these monasteries also found new communities on their own.

In this sense, we can observe a form of the globalization of monasticism understood as "transnational interdependencies" (Metzger 2012). Metzger distinguishes between three levels of consideration in a sociology of globalization: the supranational level, the transnational level and the local level. Monastic life is becoming a global reality, not only because it is present in nearly every country of the world, but because each local institution is becoming an equal part of the transnational and supranational institution. This means that young monasteries in southern countries are becoming more and more independent of their occidental founders and are taking part in transnational organizations and decision-making processes as equal members. Access to positions of abbatial authority for local monks, and access to obtaining the status of abbey by local communities are part of this process. The creation of local transnational associations or networks in countries where monasticism has recently been introduced can also be observed, like REMONAF for the liturgy as discussed above, or Saint Anne initiated by Keur Moussa for the training of young monks and nuns in Western Africa.

Another aspect of the autonomy of African monasticism is economic. I already discussed the question of pensions, but it concerns the whole African monastic economy when it deals with spending for buildings or investment as an economic activity. Katrin Langewiesche notes that African monasteries "can survive only with the help of money from the North" (Langewiesche 2015, p. 140). African monks and nuns are aware of this problem and are trying to change this fact. A Trappist monk in Kokoubou told me it is important for him that they become self-sufficient, and do not "hold out the hand beyond the ocean when [they] need to do construction" (Interview 03.2019). This question is all the more important for him because European communities have less and less possibility to help. The prior of the monastery of Agbang in Togo told me that he is aware that his monastery could not survive without the help of the congregation, but he hopes that it will be able to help German monasteries in future decades when the communities there will be too old to have sufficient revenues.

\section{Conclusions}

The future of Catholic monasticism has to be considered with a global perspective and not only concerning continents with older traditions of monastic life.

At first glance, monastic communities in Africa present exactly what European communities no longer have: a young and dynamic community, a high rate of entrants, a present dynamic of foundation, etc. But monastic communities in Africa are also confronted with different challenges which are as a result of the routinization of monastic life. The foundation of a monastery is a charismatic time where the founders-or the individual charismatic founder like the case of Agbang-are animated by a special enthusiasm. After this charismatic step, the time of routinization comes, where the monastery has to be rooted in daily life to develop a sustainable way of life. "According to Weber, all legitimate social authority is rooted in charisma, but because charisma is founded on a personal relationship between a followership and a leader, charismatic authority is inherently unstable; that is, it cannot directly survive the loss of the leader. If the social organization is to survive, some form of routinization must take place; an orderly (or routine) determination of who legitimately wields power must be determined." (Swatos 1998, online)

Some monasteries in Africa are already beyond this turning point, whereas others are now arriving at it. Monastic life in Africa will, therefore, be a very interesting topic to study in the next thirty years in order to observe its evolution. The same work could be performed in Asia, where Catholic monastic life is rooted in a context where monasticism already has a tradition in the local culture. 
Funding: This research was founding for a part by the Mariann Steegmann Foundation (Switzerland).

Conflicts of Interest: The author declares no conflict of interest.

\section{References}

Adom, Johannes. 2001. Monastère de l'Incarnation d'Agbang: Un essai d'inculturation de la vie monastique en Afrique. Mémoire de Quatrième année de Théologie. Master's thesis, University of Lomé, Lomé, Togo.

Casier, Jacques. 1974. Entry “Africa”. In Dizionario degli Istituti di Perfezione. Edited by Guerrino Pelliccia and Giancarlo Rocca. Rome: Edizione Paulina.

Cousin, Patrice. 1956. Précis d'histoire monastique. Paris: Bloud et Gay.

Dal Piaz, Giovanni. 2014. Female Monasticism in Italy: A Sociological Investigation. In Sociology and Monasticism, Between Innovation and Tradition. Annual Review of the Sociology of Religion. Edited by Isabelle Jonveaux, Enzo Pace and Stefania Palmisano. Leiden: Brill, pp. 34-54.

Delpal, Bernard. 1998. Le silence des moines. Les trappistes au XIXème siècle. Paris: Beauchesne.

Eckerstorfer, Bernhard. 2013. Monasticism and contemporary culture: Where are we going? In Monasticism between Culture and Cultures. Edited by Philippe Nouzille and Michaela Pfeifer. Rome: Studia Anselmiana, pp. 527-42.

Espagne, Michel. 2013. La notion de transfert culturel. Revue Sciences/Lettres 1: 1-9. [CrossRef]

Habermas, Rebekka. 2008. Mission im 19. Jhd. Globale Netze des Religiösen. Historische Zeitschrift 28: 631-79.

Hasquenoph, Sophie. 2009. Histoire des ordres et congrégations religieuses en France du Moyen Age à nos jours. Paris: Champs Vallon.

Hervieu-Léger, Danièle. 2000. Religion as a Chain of Memory. Chicago: Rutgers University Press.

Hervieu-Léger, Danièle. 2017. Le temps des moines. Paris: PUF.

Jonveaux, Isabelle. 2011. Le monastère au travail. Le Royaume de Dieu au défi de l'économie. Paris: Bayard.

Jonveaux, Isabelle. 2018a. Moines corps et âme. Une sociologie de l'ascèse monastique contemporaine. Paris: Le Cerf.

Jonveaux, Isabelle. 2018b. Mönch sein heute. Eine Soziologie des Mönchtums in Österreich im europäischen Dialog. Würzburg: Echter.

Langewiesche, Katrin. 2015. Transnational monasteries: The economic performance of cloistered women. Social Compass 62: 132-46. [CrossRef]

Langewiesche, Katrin. 2017. Economic Management under a Vow of Poverty: Monastic Management in Burkina Faso. In Monasticism in Modern Times. Edited by Isabelle Jonveaux and Stefania Palmisano. London: Routledge, pp. 63-78.

Lumbala, Kabelase. 2011. L'inculturation comme antidote à la violence en Afrique. Revue des Sciences Religieuses 85: 427-46. Available online: http://rsr.revues.org/1752 (accessed on 15 May 2019). [CrossRef]

Merton, Thomas. 1975. Le Retour au silence. Paris: Desclée de Brouwer.

Metogo, Eloi Messi. 1985. Théologie africaine et ethnophilosophie. Problèmes de méthode en théologie africaine. Paris: L'Harmattan.

Metzger, Jean-Luc. 2012. Que pourrait-être une sociologie de la mondialisation? Recherches sociologiques et anthropologiques HS: 87-103. [CrossRef]

Palmisano, Stefania. 2015. Exploring New Monastic Communities. The (Re) Invention of Tradition. New York: Routledge.

Ripert, Balndine. 2010. Entry “Acculturation”. In Dictionnaire des Faits Religieux. Edited by Régine Azria and Danièle Hervieu-Léger. Paris: PUF.

Sarr, Olivier-Marie. 2013. «La musique liturgique en Afrique: l'expérience de Keur Moussa (Sénégal), genèse et évolution (1963-2011)». In Atti del Congresso Internazionale di Musica Sacra in occasione del centenario di fondazione del PIMS Roma, 26 maggio-1 giugno 2011. Città del Vaticano: Libreria editrice vaticana, pp. 1347-59.

Sarr, Olivier-Marie. 2015. L'inculturazione liturgica: Fra fede celebrata e fede incarnata. Urbaniana University Journal 58: 51-75.

Schmitz, Philibert. 1949. Histoire de l'ordre de saint Benoit. Maredsous: Editions de Maredsous.

Séguy, Jean. 2014. A Sociology of Imagined Societies: Monasticism and Utopia. In Sociology and Monasticism, between Innovation and Tradition. Annual Review of the Sociology of Religion. Edited by Isabelle Jonveaux, Enzo Pace and Stefania Palmisano. Leiden: Brill, pp. 71-86. 
Swatos, William. 1998. Entry “Routinization”. In Encyclopedia of Religion and Society. Edited by William Swatos. Walnut Creek: AltaMira Press, Available online: http://hirr.hartsem.edu/ency/Routinization.htm (accessed on 30 May 2019).

Tiguila, Boniface. 2011. L'AIM, un Baobab dans le paysage africain! AIM Bulletin 102: 137-45.

Weber, Max. 1972. Wirtschaft und Gesellschaft, Grundriss der verstehenden Soziologie. Tübingen: Mohr Siebeck Verlag. Zorn, Jean-François. 1994. Les espaces de la mission. Autres Temps 43: 47-62. [CrossRef]

(C) 2019 by the author. Licensee MDPI, Basel, Switzerland. This article is an open access article distributed under the terms and conditions of the Creative Commons Attribution (CC BY) license (http://creativecommons.org/licenses/by/4.0/). 